\title{
fazendo leituras de textos sobre filosofia para crianças e jovens
}

maria teresa b.c.s. g. dos santos ${ }^{1}$ universidade de évora - portugal

Alice Santos publicou Maria Vinagre e João Roupeiro. Das raparigas e dos rapazes, editado pelo Centro de Formação de Escolas do Concelho de Almada, em 2014, apenas lançado em 2015. Da leitura atrasada, por demorar noutras leituras, sublinho quer a escrita forte e incisiva, marca duma obrigação intelectual e moral, quer o tema da relação entre géneros. Um tema que aborda pela combinação da razão, do afecto e da experiência do corpo. Um tema que prova que a relação entre géneros não é esporádica mas incessante. Um tema inadiável para que não torne irreparavelmente ininteligível e humanamente divisionista aquilo que se passa no corpo e na relação com os corpos. Da leitura fixo três breves pontos.

O primeiro ponto a considerar é contextualizador. Trata-se do quinto livro que a autora publica no âmbito de Filosofia com Crianças e Jovens, daí que comece por saudar e destacar o seu renovado contributo no avolumar da bibliografia portuguesa, com textos e actividades originais. Mais do que fornecer materiais para dinamizar sessões de Filosofia com Jovens entre os 11 e 14 anos de idade, o livro de Alice Santos assenta no pressuposto de que a Filosofia é, sem ferir o seu significado objectivo, uma iniciação ao exercício de "pensar correctamente com" os outros e de com eles deslindar os usos da razão que induzem a afirmar, negar, associar, questionar, auto-corrigir, mas também a desviar ou contorcer o sentido das palavras. No propósito que anima o texto a autora não esconde a influência de Óscar Brenifier, conhecido pelo modo como radicaliza o exercício de estar atento à relação imediata entre a pergunta e a resposta. Daí que a expressão "pensar correctamente com" não remeta para a aplicação duma normatividade reguladora do pensamento mas seja exigência dum exercício que só ganha significado filosófico quando questiona além da superfície do que se pensa e sente. Por conseguinte o livro não deve ser encarado e utilizado como um manual didáctico

\footnotetext{
${ }^{1}$ E-mail: msantos@uevora.pt
} 
prêt à porter equivalente a um catecismo com perguntas possíveis, tendência editorial que começa a atrair praticantes de Filosofia para Crianças em Portugal. De facto não são as perguntas destes catecismos que se põem em causa, quase sempre bem ajustadas aos textos, mas o esquecimento de dois aspectos decisivos em Filosofia: um, a prioridade e a liberdade da criança/jovem formular questões; outro, o exercício de radicalização da resposta da criança/jovem com as/os outras/os crianças/jovens. É pouco provável que quem não seja interpelado filosoficamente por um texto, e por isso recorre a uma lista de questões feitas, saiba escutar, discernir e radicalizar o que na resposta de crianças e jovens aflora de potencialmente filosófico ou manifestamente falacioso. Se Alice Santos reivindica para o pensamento crítico um espaço dentro da escola e uma presença transversal ao curriculum a todos os níveis de ensino não é para aplicar um receituário de perguntas mas dar lugar ao exercício de investigação em comunidade sobre questões que sendo particulares também são universais e que partindo de narrativas imaginadas também são vivências reais do ser humano, enquanto sujeito de pensamento, de sentimentos, de acção e de presença. Neste sentido o livro inscreve-se na linha duma pedagogia fundamental que prioriza a escuta, seja da palavra do texto, seja da palavra oral, sobre a qual se alicerça uma praxis dialógico-argumentativa em permanente exercício interrogativo na busca de sentidos.

O segundo ponto a considerar diz respeito à estrutura do livro que está seccionado em duas partes: a narrativa (p. 5-77) e as propostas de trabalho (p. 79125). A repartição por duas secções é adoptada do modelo criado por Matthew Lipman e Ann Sharp. Alice Santos, que fez formação no Institute Advancement of Philosophy for Childrem (IAPC) da Universidade de Montclair (USA), apropriouse, no sentido discipular, da estrutura usada e por isso dá continuidade ao método narrativo (novel) e à fixação de exercícios (lesson plans \& activities). A autora escreve uma narrativa em formato de novela, com personagens a iniciarem a adolescência em vivências reconhecidas como comum. A novela é sequenciada por cenas várias, onde os jovens estão em interacção com a família, os amigos, os 
colegas e os professores. Não há no livro o maravilhoso literário; o quotidiano já dá muito que pensar. É no quotidiano que se colocam as questões basilares do livro: a identiddae, a alteridade e a interacção. E neste sentido Alice Santos não só desbanaliza o quotidiano "ram-ram" dos jovens, como o eleva ao nível da problematização, em que o particular da situação se alarga a um colectivo que não sabe abordar com naturalidade a presença sensorial do corpo que a partir de certo momento se impõe com a dimensão de um alter ego. É no início da adolescência que certas questões se configuram num misto de agudeza enunciativa e de convulsão emotiva e ganham densidade corporal. A questão da identidade sexuada é uma dessas questões que mescla a expressão racional com a expressão emocional e fisica. Do ponto de vista formal a novela segue critérios bem definidos:

- Organização coerente dos elementos da história

- Inclusão duma diversidade de opiniões e perspectivas

- Presença de temas filosóficos (identidade, alteridade e interacção)

- Incitação ao questionamento

- Ausência de tentativas de moralização ou doutrinação

- Originalidade da história e dos exercícios

- Recurso a diversas capacidades do pensamento, como a hipótese, o exemplo, o contra-exemplo, a definição, a analogia, a consequência, o critério, entre outros.

A segunda secção do livro tem um caderno que permite a cada leitor aprofundar o seu pensamento e participar no diálogo (pensar com os outros mediante a narrativa) pela escrita. Se há jovens que não mostram grande aptidão para a participação no jogo oral, há outros que preferem a escrita, menos expositiva e mais intimista. Por outro lado, a escrita permite ser revisitada e assim ser auto-avaliada (não no sentido quantitativo) e auto-corrigida.

O terceiro ponto a considerar decorre duma apreciação de carácter geral. Um dos aspectos notáveis do livro é a escolha de questões significativas para os jovens e com actualidade: o corpo, o género, a relação. O título é claramente 
indicador desta intencionalidade que organiza o conteúdo: Maria Vinagre e João Roupeiro. Das raparigas e dos rapazes. O corpo que começa a responder a novas funções e solicitações, a identidade de género que se constrói em estereótipo ou hesita em assumir-se ou suspeita desconfortavelmente de si, e a relação que se estende por redes complexas, são matéria interrogativa dos jovens para a qual nem sempre se encontra um registo enunciativo capaz de a introduzir no diálogo. E este desencontro entre sentir, pensar e falar sobre matéria tão significativa pode ser superado com a leitura do livro de Alice Santos.

A novela está repartida por nove situações diferentes, dispostas num crescendo de inteligibilidade. Vão-se adensando as questões sobre identidade, alteridade e interacção e vão-se reconfigurando as tensões emocionais com a família, os amigos e os colegas. É interessantíssima a paleta de reacções e sentimentos. Para exemplificar retiro do texto algumas palavras, sem qualquer preocupação com a classe morfológica a que pertencem: raiva, choro, negação, curiosidade, boato, gozar, isolamento, ganhar coragem, reconciliação, cumplicidade, furioso, aconchego,... Em todas elas se reconhecem entradas para abordar questões da identidade, alteridade e interacção. Questões nunca esgotadas e onde resistem afloramentos de preconceitos, estereótipos e violência.

O livro pode ser analisado em diversos planos. Recorto três planos. 1) Cada situação trata dum tema interessante. Por exemplo, no primeiro capítulo aborda-se a confidencialidade e o seu oposto, a traição. Em diversos capítulos a autora introduz pares amorosos, que tanto podem ser interpretados como contexto simbólico para apresentar a descoberta da relação entre Maria Vinagre e João Roupeiro, como podem ser entendidos como um piscar de olho conciliador com a cultura clássica, cuja hermenêutica simbólica os jovens podem pesquisar através da net. 2) Actualização dos grandes quadros e cenas amorosas. Orfeu e Eurídice introduzem, no primeiro capítulo, o tema da confiança. D. Quixote e Dulcineira comemoram o amor platónico sem fronteiras nem restrições. Romeu e Julieta, evocam o amor contrariado mas profundamente cúmplice. Cúmplice até na própria morte. D. Pedro e D. Inês simbolizam o amor contrariado mas 
inesquecível e por isso invencível e intemporal. 3) Reconstituição do diálogo entre Sócrates e seus discípulos. Um diálogo sobre o amor, a amizade, a paixão e a

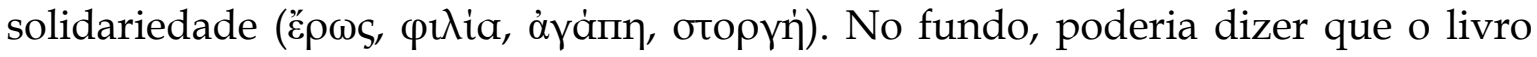
Maria Vinagre e João Roupeiro. Das raparigas e dos rapazes retoma, mutatis mutandis, o Banquete de Platão, onde Sócrates discute com os seus discípulos a natureza e a diversidade de manifestações do amor. Mas o livro também tem referências contemporâneas, por via da expressão "power of love", título duma canção de Celine Dion, ou "Estar Apaixonado" outro título que remete para o cantor compositor Pedro Abrunhosa. Enfim, não faltam possibilidades para explorar a matéria. Daí que este seja um livro que se recomenda para ler, dar a ler e abrir diálogo.

recebido em: 05.02.2017

aceito em: 08.03.2017 